\title{
ASSESSMENT OF THE ECONOMIC POTENTIAL OF THE ENTERPRISE
} Pavel I. Razinkov ${ }^{1}$, Dmitry V. Martynov ${ }^{2}$, Oksana P. Razinkova ${ }^{3}$

${ }^{1}$ Doctor of Economics, Professor, Head of the Department of Management of Tver State Technical University, Tver Region, Tver, Russia, ${ }^{2}$ Candidate of Technical Sciences, Associate Professor of Information Systems Department, Tver State Technical University, Tver Region, Tver, Russia, ${ }^{3}$ Candidate of Economic Sciences, Associate Professor of the Department of Management of Tver State Technical University, Tver Region, Tver, Russia. Email: ${ }^{1,2}$ men_756@mail.ru, ${ }^{3}$ razinkovaoksana@mail.ru

\section{Article History: Received on $21^{\text {st }}$ August 2019, Revised on $29^{\text {th }}$ September 2019, Published on $06^{\text {th }}$ November 2019}

\begin{abstract}
Purpose of the study: The article deals with the problems of forming and increasing the efficiency of using the basic production assets of an enterprise.

Methodology: Methods of working with physically challenged children (PCC) are described in the works by V .V.Linkov, N .N. Malofeev, N. M. Nazarov, etc. They consider various methods and techniques of organizing educational work with children having health problems.
\end{abstract}

Results: The analysis of the effectiveness of the formation and use of the basic production assets of a machine-building enterprise has been carried out, and measures have been considered to improve their formation and use.

Applications of this study: This research can be used for the universities, teachers, and students.

Novelty/Originality of this study: In this research, the model of assessment of the economic potential of the enterprise is presented in a comprehensive and complete manner.

Keywords: fixed production assets, capital productivity, capital intensity.

\section{INTRODUCTION}

In the conditions of the market economy, and, especially, unstable production, it is important to increase the efficiency of formation and use of the main production assets of the enterprise. An important role in the implementation of this task is given to the renewal of the main productive funds since it is possible to increase the technical level of production and innovative development of the enterprise during the formation of their composition and structure. To solve this problem, it is necessary to ensure the restructuring of production and an increase in the competitiveness of the enterprise on the basis of the introduction of effective management forms and modern methods of production management.

It should be noted that little attention was paid to the formation of the composition and structure of the main productive assets at the enterprises in recent years. This has led to aging and a decrease in the efficiency of their use and updating. Thus, during the period of economic restructuring at the end of the last century, and the crises in 2008 and 2014 , sharp drops in volumes of products manufactured by the enterprises took place, which in turn led to a sharp decrease in the loading of fixed assets and production capacities of most enterprises.

In spite of the planned growth of industrial production by $1.5 \%$ in 2017 and by about $2 \%$ in 2018 , Russia's economy is still in crisis, the outcome of which, because of the presence of sanctions, can be implemented only on the basis of revealing production reserves and reducing impact of most factors that negatively affect the innovative renewal of the main productive assets and production facilities of the enterprise.

The need for technical re-equipment of enterprises is also due to the fact that the main industrial funds of the industry, despite their economic homogeneity, according to certain groups, have their own specifics of the production purpose of their various structural components and types. This is due to the fact that the main productive assets of the enterprises differ in the role of each element in the production process and branch affiliation, as well as in the unevenness of their physical and moral wear, which characterize the technical condition of the main production assets and their ability to innovate the development of the enterprise. (Razinkova, O.P. 2018; Shepelenko, G.I. 2010; Strazheva, N.S. 2004; Titov, V.I. 2008).

The experience of highly developed countries shows that the innovative development of the economy calls for the full use of technologies of the fifth technological system. According to this indicator, our country is still far behind the highly developed countries. The task is complicated by the fact that the world is on the verge of the introduction of technologies of the sixth technological system, that is, breakthrough technologies, the possession of which allows for a higher level of technological development. Consequently, it is necessary to develop a new strategy for the conduct of enterprises in the commodity market, where an increase of the technical level, quality, and reliability of the manufactured products is at the forefront, which depends entirely on the progressiveness of the applied technology and the technical condition of fixed assets.

Considerable attention is paid to the study of the effectiveness of the formation and use of the main production assets of the enterprise, as well as the clarification of their concept and essence as an economic category. Thus, Levkovich O. A. and 
Burtseva I.N. define the fixed assets as the cost expression of labor means repeatedly participating in the production processes, constantly wearing out, as well as the amounts of this wear, carrying their value to finished products (works, services)".

Almost similarly, the essence of the basic production assets was formulated by Yu.A. Yeleneva; Strazheva N.S. and Strazhev A. V., Shepelenko G. I. et al. They note that "the main production assets are the labor means involved in the production process for a long time, while maintaining their natural form, and that their value is transferred to the finished products in parts, as fixed assets wear out".

Gilyarovskaya L. T., Kornelov G. V., Plaskova N. S., et al. believe that "the main production assets are those production means that function directly in the production field and transfer their value to the finished product gradually, as they wear out, over many production cycles, retaining their natural form" (Karlik, A.E. 2010; Levkovich, O.A. 2017).

Taking into account the views of the above and other authors, we believe that the basic production assets are a more capacious and complex economic category. The defining feature of the basic production assets is the structure of the labor objects at the enterprise, which has the ability to ensure the production process of manufacturing a specific type of product according to the technology that ensures its maximum possible competitiveness (Razinkov, P.I. 2018). According to their economic essence, the main production assets are formed from the volumes spent on the acquisition of funds and transfer their value to the product gradually and in parts in accordance with the production cycles of product manufacturing. The duration of such cycles is determined by the moral and physical deterioration of fixed assets during their operation.

The fixed assets of the enterprise are divided into production and non-production assets. The production means directly involved in the production process or creating the conditions for its implementation are usually referred to as fixed production assets.

The objects of cultural and household purposes, residential buildings that are on the balance sheet of the enterprise are classified as major non-productive funds. Non-productive fixed assets do not participate in the production process but are an important social factor influencing the stimulation of high-performance labor of the personnel of the enterprise and an increase in the material and cultural standard of living of the personnel of the enterprise.

On the basis of the economic essence of the labor means, fixed assets are usually attributed to that part of the production assets that have been participating for a long time in the production process and retaining their natural form at the same time. The basic production assets are usually divided into the following groups: buildings and structures; facilities; transfer devices; working machines and equipment; measuring and regulating appliances and devices; vehicles; tools and fixtures; household equipment.

In addition, the fixed assets include: working and productive livestock; perennial plantations; other fixed assets, etc.

However, this classification and content of the composition of its elements require some clarification and specification. It is caused by the fact that there have been significant changes in the technology of manufacturing products, organizing labor production, etc. in recent years. This necessitates some clarification of the classification and allocation of certain structural elements of fixed production assets into separate groups. These are:

1. Production buildings, in which the production process is carried out, including the building of procurement and subsidiary production; (Razinkova, O.P. 2018; Shepelenko, G.I. 2010; Strazheva, N.S. 2004; Titov, V.I. 2008).

2. Treatment facilities. As a separate element of fixed assets, sewage treatment plants are to be separated, because they are expensive in most cases and some of them are included in city-wide purification systems;

3. Technological installations that determine the profile of the enterprise;

4. Machine park and technological conveyors, technological lines, flexible production systems and other high-tech components of the active part of fixed assets;

5. Factory monitoring laboratories, testing stations, polygons, etc.

It is also desirable to exclude tools from the composition and structure of fixed assets; inventory and accessories regardless of their value and their service life.

Experience shows that the separation of their active and passive parts into separate groups positively affects the search for reserves of the effectiveness of using basic production assets. The active part is the working machines and technological equipment directly involved in the production process, as well as control-regulating and measuring devices and other devices, the use of which is established by the technological process of product manufacturing. The passive part of the basic production assets shall include those that are designed to maintain the effective functioning of the production process of product manufacturing. The fixed production assets of the enterprise are also usually classified according to their affiliation with the production process and the owner. These are: own funds that are on the balance sheet of the enterprise; rented (temporarily used for payment received under leasing); acting; in stock or in conservation; in installation or at the warehouse. In many cases, it is necessary to subdivide the main production assets by the duration of their operation. 
Improving the classification of the structure of basic production assets will allow the enterprise obtaining more complete data on the quantitative and qualitative composition of the structural components of the basic production assets and form their structure more purposefully. In addition, the company will be able to change the ratio of individual groups of fixed assets in their total volume and calculate the reserves for improving the efficiency of their formation and use.

The effectiveness of formation and use of basic production assets is greatly influenced by the factors of external and internal environment, the main ones among them are: economic factors (dynamics of production volumes and sales of products, availability of profit and increase in profitability of the enterprise, qualitative composition of the labor resources of the enterprise, etc.); technical factors (presence and movement of basic production assets, their structural composition, level of technologies used, degree of implementation of the achievements of scientific and technological progress, etc.); organizational factors (organizational level of production, motivational system of personnel, rhythm and uniformity of production, etc.) and social factors (level of labor remuneration of personnel, provision of workers with special food, overalls and others). In some cases, psychological factors can also be identified, whose role is increasing with the development of communication processes. Considering the influence of particular factors, it is possible to achieve an increase in the efficiency of the formation and use of fixed production assets of the enterprise, to select and evaluate indicators affecting the efficiency of the enterprise. The problem of developing indicators for evaluating the efficiency of using basic production assets was the focus of attention of such scientists as V. Ya. Gorfinkel, O. V. Antonov, A. O. Blinov, I. N. Vasiliev, A. E. Karlik, A. I. Nechitailo, V. I. Titov (Razinkova, O.P. 2018; Shepelenko, G.I. 2010; $\underline{\text { Strazheva, }}$ N.S. 2004; Titov, V.I. 2008). They and other authors propose to subdivide all indicators of the use of fixed production assets into generalizing and private ones. As a summary, they propose to use such indicators as:

1. Capital productivity ratio, which characterizes the number of products, in value terms per one rouble of the value of basic production assets;

2. Capital output ratio of products, reflecting the value of fixed assets attributable to the rouble of output;

3. Capital labor ratio, determined by the ratio of the value of fixed assets (in comparable prices) to the average headcount of the enterprise;

4. Mechanized labor ratio, which is determined by dividing the total average annual cost of the active part of basic production assets by the average number of basic production workers.

It is important to note that the indicator of capital productivity ratio reflects how effectively the labor embodied in the basic production assets is used. The indicator of the capital-output ratio of products is the value, which is contrary to capital productivity ratio. In our opinion, a more acceptable indicator is the capital-output ratio of products, since it more fully characterizes the economic essence of fixed production assets. The indicator of the capital-labor ratio characterizes the equipment of workers in the production field with basic production assets. The indicator of mechanized labor ratio characterizes the ratio of the cost of active part of the basic production assets per worker of the main production. However, these indicators do not allow fully assessing the degree of using fixed assets of the enterprise, therefore, their evaluation shall be supplemented with indicators of return on assets, reproduction and turnover of fixed production assets, etc (Yeleneva, Yu.A. 2009; Gilyarovskaya L.T. 2015).

\section{RESEARCH METHODS}

The efficiency of using fixed production assets can be assessed not only by generalizing but also by many particular indicators. These are the ratios of extensive and intensive use of technological equipment. The following indicators are used for evaluation:

1. Extensive equipment use factor, determined as the ratio of the actual number of hours of the equipment operation to the planned number of working hours;

2. Equipment shift working factor, determined by the ratio of the total number of machine-shifts operated by the equipment to the total number of units of installed equipment.

3. Equipment load factor, determined by the labor intensity ratio of manufacturing all the products on this type of equipment to the planned operating time fund.

4. Intensive equipment use factor, determined as the ratio of the actual (planned) volume of output to the capacity (productivity) of equipment.

5. Summarizing integral indicator of intensive and extensive equipment use, determined by the product of intensive and extensive equipment use ratios.

\section{RESULTS}

The estimated value of the integral indicator will always be lower than the calculated values of the extensive and intensive equipment use ratios of the enterprise. So while improving, for example, the intensive use of technological equipment, all other things being equal, its operation time decreases and, conversely, the value of one of the indicators increases or decreases as a result. 
It is important for the enterprise to make calculations of the use of technological equipment in the dynamics of the analyzed and base periods. This will allow characterizing the use of potential capabilities of the enterprise for the production of products on the existing fixed production assets. The calculation is carried out according to the formula:

$$
\mathrm{B}=\frac{\mathrm{M}_{\mathrm{ef}} * N}{\mathrm{t}_{\mathrm{pCs}}} \text { or }
$$

Where B - output volume;

$\mathrm{M}_{\mathrm{ef}}$ - production capacity of the equipment;

$\mathrm{N}$ - number of equipment pieces, performing this operation;

$\mathrm{t}_{\mathrm{pcs}}$ - technically calculated rate of time for processing (manufacturing) the product piece.

One of the important factors of increasing production volumes at industrial enterprises is the availability of fixed production assets in the required optimal quantity and range, as well as their more complete and effective use. This necessitates the analysis and study of the volume of fixed production assets, their dynamics, structure, allocation of the active part (working machines, equipment, etc.), passive part of fixed assets and individual subgroups in accordance with their specific structure.

Such detailing should be carried out in order to optimize the structure of fixed production assets and to identify reserves for increasing the efficiency of their formation and use. The calculation of the ratio of active and passive parts of fixed assets is of great interest, since the level of capital productivity ratio, return on assets and financial condition, as well as other indicators of the enterprise's work, largely depends on their optimal ratio. Hrustalev, B. B., \& Uchaeva, T. V. (2014).

Table 1: The structure of fixed assets

\begin{tabular}{lllll}
\hline Indicators & Period & $\begin{array}{l}\text { Deviation }(+; \\
-)\end{array}$ & $\begin{array}{l}\text { Growth } \\
\%\end{array}$ & rate, \\
\cline { 2 - 5 } & 2017 & 2018 & 101784 & 147.18 \\
\hline Total fixed assets, incl. & 215750 & 317534 & 4386 & 105.10 \\
\hline Buildings and structures & 85952 & 90338 & 117606 & 238.08 \\
\hline Machinery, equipment, vehicles & 85170 & 202776 & 1306 & 116.77 \\
\hline $\begin{array}{l}\text { Other types of fixed assets } \\
\text { Fixed assets leased }\end{array}$ & 7789 & 9095 & -21514 & 41.60 \\
\hline $\begin{array}{l}- \text { active part of HPF (hazardous } \\
\text { production factor) }\end{array}$ & 124987 & 15325 & 96326 & 177.07 \\
\hline - passive part of HPF & 90763 & 9621313 & 5458 & 106.01 \\
\hline
\end{tabular}

Table 1 shows that the value of the basic production assets increased by 101784 thousand roubles or $47.2 \%$ in 2018 in comparison with 2017. The cost of machinery, equipment, and vehicles increased to the greatest extent (by 138.08\%), which led to an increase of $77.07 \%$ in the active part of the plant's fixed assets. This increase in the share of the active part in the total composition of fixed assets was due to the replacement of outdated universal technological equipment with a new, more productive one. So, the plant purchased new numerically controlled machine tools, electric welding machines, special aggregate machines, automatic lathes and semi-automatic machines, die-casting machines in a vacuum mold, and other modern process equipment in the analyzed period. The changes that have occurred have significantly improved the use of the plant's fixed assets. The calculation data are presented in Table 2. Babkin, A. V. (2013).

Table 2: Indicators characterizing the change in the technical condition and use of fixed production assets of Mashinostroitelny Zavod JSC for 2017-2018

\begin{tabular}{|c|c|c|c|c|}
\hline \multirow{2}{*}{ Indicators } & \multicolumn{2}{|l|}{ Period } & \multirow{2}{*}{$\begin{array}{l}\text { Deviation }(+; \\
-)\end{array}$} & \multirow{2}{*}{$\begin{array}{l}\text { Growth rate, } \\
\%\end{array}$} \\
\hline & 2017 & 2018 & & \\
\hline $\begin{array}{l}\text { Cost of manufactured products, } \\
\text { thousand roubles }\end{array}$ & 1320049 & 1550169 & 230120 & 117.43 \\
\hline Personnel average number & 610 & 712 & 102 & 116.7 \\
\hline Return on assets & 221.92 & 117.98 & -103.94 & $\mathrm{x}$ \\
\hline Capital productivity ratio, HPF & 18.04 & 9.51 & -8.53 & 52.7 \\
\hline Active capital productivity ratio, HPF & 31.12 & 16.4 & -14.72 & 52.7 \\
\hline Capital output ratio & 0.055 & 0.11 & 0.055 & 200.0 \\
\hline Labor $\quad$ productivity, & 2164.0 & 2177.2 & 13.2 & 100.6 \\
\hline
\end{tabular}




\begin{tabular}{llllll}
\hline roubles/person. & \multicolumn{2}{l}{} & & & \\
\hline $\begin{array}{l}\text { Capital labor ratio, } \\
\text { roubles/person }\end{array}$ & thousand & 119.94 & 229.05 & 109.11 & 191.0 \\
\hline $\begin{array}{l}\text { Mechanized labor } \\
\text { roubles/person }\end{array}$ & ratio, thousand & 142.3 & 159.4 & 17.1 & 112.0 \\
\hline Renewal factor & 0.2467 & 0.4316 & 0.1849 & $\mathrm{X}$ \\
\hline Renewal term, years & 3.29 & 1.57 & -1.72 & $\mathrm{X}$ \\
\hline Retirement factor & 0.09 & 0.163 & 0.073 & $\mathrm{X}$ \\
\hline Growth factor & 0.2178 & 0.4718 & 0.254 & $\mathrm{X}$ \\
\hline Wear factor & 0.6138 & 0.3646 & -0.2492 & $\mathrm{X}$ \\
\hline Service life factor & 0.3862 & 0.6354 & 0.2492 & $\mathrm{X}$ \\
\hline
\end{tabular}

Table 2 shows that the values of many indicators characterizing the movement and technical condition of the plant's fixed assets have improved. The renewal factor concerning fixed assets more than doubled, their retirement accelerated and their wear decreased. However, many indicators of formation and use have deteriorated significantly due to a sharp increase in the applied fixed assets. Thus, the capital productivity ratio of fixed assets as a whole and their active part decreased by $47.3 \%$, and the capital-output ratio increased twice. Labor productivity increased by only $0.6 \%$. But on the whole, the plant has great opportunities to increase the efficiency of using fixed assets, since the opportunity to increase production volumes appeared, there was an increase by 109.11 thousand roubles in capital-labor ratio and 17.1 thousand roubles in mechanized labor ratio. This made it possible to increase the production volume by $17.4 \%$ and significantly improve the indicators of using fixed production assets, including the plant's technological equipment. Data on the use of technological equipment of Mashinostroitelny Zavod JSC is presented in Table 3.

Table 3: Indicators of using technological equipment of Mashinostroitelny Zavod JSC for 2017-2018

\begin{tabular}{|c|c|c|c|c|}
\hline \multirow{2}{*}{ Group of fixed assets } & \multicolumn{2}{|l|}{ Period } & \multirow{2}{*}{$\begin{array}{l}\text { Deviation }(+; \\
-)\end{array}$} & \multirow{2}{*}{$\begin{array}{l}\text { Growth } \\
\%\end{array}$} \\
\hline & 2017 & 2018 & & \\
\hline Technological equipment installed & 227 & 312 & 85 & 133.0 \\
\hline Technological equipment used & 234 & 321 & 87 & 137.18 \\
\hline Shift factor & 1.0 & 1.0 & 0 & $\mathrm{X}$ \\
\hline $\begin{array}{l}\text { Utilization rate of the available } \\
\text { equipment fleet, } \mathrm{K}_{\mathrm{a}}\end{array}$ & 0.9286 & 0.9198 & -0.0088 & $\mathrm{X}$ \\
\hline $\begin{array}{l}\text { Utilization rate of the installed } \\
\text { equipment fleet, } \mathrm{K}_{\mathrm{ue}}\end{array}$ & 0.975 & 0.973 & -0.002 & $\mathrm{X}$ \\
\hline $\begin{array}{l}\text { Calendar fund of time, machine hours, } \\
\mathrm{T}_{\mathrm{c}}\end{array}$ & 2102400 & 2890800 & 788400 & 137.5 \\
\hline $\begin{array}{l}\text { Regime fund of time, machine hours, } \\
T_{r}\end{array}$ & 480000 & 660000 & 180000 & 137.5 \\
\hline $\begin{array}{l}\text { Planned fund of time, machine hours, } \\
T_{p}\end{array}$ & 464520 & 638715 & 174195 & 137.5 \\
\hline $\begin{array}{l}\text { Actual fund of hours worked, machine } \\
\text { hours, } T_{a}\end{array}$ & 430372.8 & 595163 & 164790.2 & 138.3 \\
\hline $\begin{array}{l}\text { Utilization rate of the calendar time } \\
\text { fund, } \mathrm{K}_{\mathrm{cf}}\end{array}$ & 0.2047 & 0.2059 & 0.0012 & $\mathrm{x}$ \\
\hline $\begin{array}{l}\text { Utilization rate of the regime time } \\
\text { fund, } K_{\mathrm{rf}}\end{array}$ & 0.8966 & 0.9018 & 0.0052 & $\mathrm{X}$ \\
\hline $\begin{array}{l}\text { The utilization rate of the planned time } \\
\text { fund, } K_{\mathrm{pf}} \\
\text { (Extensive equipment use factor) }\end{array}$ & 0.9265 & 0.9318 & 0.0053 & $\mathrm{X}$ \\
\hline $\begin{array}{l}\text { The specific gravity of downtime in } \\
\text { the calendar fund, } \mathrm{UD}_{\mathrm{d}}\end{array}$ & 0.0111 & 0.0092 & -0.0019 & $\mathrm{X}$ \\
\hline Extensive equipment use factor & 0.8763 & 0.7442 & -0.1321 & $\mathrm{X}$ \\
\hline Integral equipment use factor & 0.8119 & 0.6934 & -0.1185 & $\mathrm{X}$ \\
\hline
\end{tabular}

According to the data presented in Table 3, we can conclude that 87 units of new equipment were installed at the plant. Its use slightly decreased in 2018 compared with 2017. So, with the shift factor equal to one, the use of available and installed equipment fleet decreased, and the values of its intensive and integral use factors also decreased. It is inherent that the plant has improved planning for the use of regime, extensive, calendar time and the use of planned funds of time characterizing the level (ratio) of extensive equipment use. As expected, its value has improved significantly since $\mathrm{K}_{\mathrm{pf}}$ reached 0.9318 in 2018. 


\section{CONCLUSION}

The efficiency of using basic production assets can be improved by increasing the level of using their passive part of industrial and administrative buildings, as well as using other areas where the company is located. To assess the effectiveness of their use, the utilization rate of the area they occupy is applied. This indicator is calculated as (the ratio of the area occupied by the equipment to the total production area).

In our opinion, it is necessary to separately calculate the utilization rate of warehouse space. Knowledge of the values of these factors will allow estimating not only the level of using the areas occupied by raw materials, materials, etc. but also the equipment installed in the warehouses. It is also important to assess the use of the territory belonging to the enterprise. The level of using the enterprise's space can be estimated using the following indicators: removal of products from 1 sq. m.: occupied by equipment; production area; available area and utilization of warehouse space, etc.

However, the main reserves of optimizing the use of fixed production assets for Mashinostroitelny Zavod JSC consist in increasing the shift of equipment operation, reducing the level of day-to-day and all-day equipment downtime. Increasing the intensity of using fixed production assets, especially their active part, in turn, can be achieved by: improving the composition and structure of fixed production assets; introduction of advanced methods of work organization and production technology; application of the system of scientific organization of labor; automated production management systems; mechanization and automation of production processes; improving the skills of workers servicing technological equipment; stimulating the work of personnel and other factors of forming and increasing the efficiency of using the fixed production assets of the enterprise.

\section{REFERENCES}

1. Gilyarovskaya L.T. (2015). Economic analysis / L.T. Gilyarovskaya, G.V. Kornelov, N.S. Plaskova, G.N. Sokolova, G.A. Pozhidaeva, D.A. Endovitsky. M.: Yuniti-Dana. 2015. 318 p.

2. Gorfinkel, V.Ya. (2013). Enterprise Economics. V.Ya. Gorfinkel, O.V. Antonov, A.O. Blinov, I.N. Vasilieva. M.: Yuniti-Dana. 2013. 663 p.

3. Karlik, A.E. (2010). Economics of Enterprises (Organizations) / A.E. Karlik, A.I. Nechitailo. M.: Prospekt. 2010. 304 p.

4. Levkovich, O.A. (2017). Accounting / O.A. Levkovich, I.N. Burtseva. Minsk: Amalfeya, 2017. 607 p.

5. Razinkov, P.I. (2018). Analysis of the Effectiveness of the Enterprise's Potential / P.I. Razinkov. Publishing House of the TvSTU. 2018. 256 p.

6. Razinkova, O.P. (2018). Enterprise's Potential: Conceptual Bases of Formation and Development / O.P. Razinkova. Publishing House of the TvSTU. 2018. 200 p.

7. Shepelenko, G.I. (2010). Economics, Organization and Production Planning at the Enterprise / G.I. Shepelenko. Rostov on Don: Feniks. 2010. 600 p.

8. Strazheva, N.S. (2004). Accounting / N.S. Strazheva, A.V. Strazhev. Minsk. Knizhny Dom. 2004. 432 p.

9. Titov, V.I. (2008). Enterprise Economics / V.I. Titov. M.: Eksmo. 2008. 416 p.

10. Yeleneva, Yu.A. (2009). Economics of Engineering Production / Yu.A. Yeleneva, M.: Akademiya, 254 p.

11. Hoogwijk, M., de Vries, B., \& Turkenburg, W. (2004). Assessment of the global and regional geographical, technical and economic potential of onshore wind energy. Energy Economics, 26(5), 889-919. https://doi.org/10.1016/j.eneco.2004.04.016

12. Milkov, A. V., \& Sassen, R. (2003). Preliminary assessment of resources and economic potential of individual gas hydrate accumulations in the Gulf of Mexico continental slope. Marine and Petroleum Geology, 20(2), 111-128. https://doi.org/10.1016/S0264-8172(03)00024-2

13. Bryan, B. A., Ward, J., \& Hobbs, T. (2008). An assessment of the economic and environmental potential of biomass production in an agricultural region. Land Use Policy, 25(4), 533-549. https://doi.org/10.1016/j.landusepol.2007.11.003

14. Juhlin, C., \& Sandstedt, H. (1989). Storage of nuclear waste in very deep boreholes: Feasibility study and assessment of economic potential. Pt. 1 and 2 (No. SKB-TR--89-39). Swedish Nuclear Fuel and Waste Management Co..

15. Roberts, K. G., Gloy, B. A., Joseph, S., Scott, N. R., \& Lehmann, J. (2009). Life cycle assessment of biochar systems: estimating the energetic, economic, and climate change potential. Environmental science \& technology, 44(2), 827-833. https://doi.org/10.1021/es902266r

16. Taylor, A. N. D. R. E. W., Lindsey, P. A., Davies-Mostert, H. A. R. R. I. E. T., \& Goodman, P. E. T. E. R. (2015). An assessment of the economic, social and conservation value of the wildlife ranching industry and its potential to support the green economy in South Africa. Johannesburg, South Africa: The Endangered Wildlife Trust, 1-163.

17. Schneider, L., Berger, M., Schüler-Hainsch, E., Knöfel, S., Ruhland, K., Mosig, J., ... \& Finkbeiner, M. (2014). The economic resource scarcity potential (ESP) for evaluating resource use based on life cycle assessment. The International Journal of Life Cycle Assessment, 19(3), 601-610. https://doi.org/10.1007/s11367-013-0666-1

18. Mondal, M. A. H., \& Denich, M. (2010). Assessment of renewable energy resources potential for electricity generation in Bangladesh. Renewable and Sustainable Energy Reviews, 14(8), 2401-2413. https://doi.org/10.1016/j.rser.2010.05.006 
19. Perry, B. D., \& Randolph, T. F. (1999). Improving the assessment of the economic impact of parasitic diseases and of their control in production animals. Veterinary parasitology, 84(3-4), $145-168$. https://doi.org/10.1016/S0304-4017(99)00040-0

20. Datta, R., Tsai, S. P., Bonsignore, P., Moon, S. H., \& Frank, J. R. (1995). Technological and economic potential of poly (lactic acid) and lactic acid derivatives. FEMS microbiology reviews, 16(2-3), 221-231. https://doi.org/10.1111/j.1574-6976.1995.tb00168.x

21. Xie, Y., Raymo, J. M., Goyette, K., \& Thornton, A. (2003). Economic potential and entry into marriage and cohabitation. Demography, 40(2), 351-367. https://doi.org/10.1353/dem.2003.0019

22. Schneider, U. A., \& McCarl, B. A. (2003). Economic potential of biomass based fuels for greenhouse gas emission mitigation. Environmental and resource economics, 24(4), $291-312$. https://doi.org/10.1023/A:1023632309097

23. Hoogwijk, M., de Vries, B., \& Turkenburg, W. (2004). Assessment of the global and regional geographical, technical and economic potential of onshore wind energy. Energy Economics, 26(5), 889-919. https://doi.org/10.1016/j.eneco.2004.04.016 